\title{
Doing the Corporate Business with Piercing the Corporate Veil Doctrine: Indonesia, Us And Uk Perspective
}

\author{
$\mathrm{Ng}$ Catharina Enggar Kusuma and Fl. Yudhi Priyo Amboro* \\ International University of Batam, Indonesia \\ *yudhi.amboro@gmail.com
}

Published: 15/08/2020

How to cite: Kusuma, N. C. E., \& Amboro, F. Y. P. (2020). Doing the Corporate Business with Piercing the Corporate Veil Doctrine: Indonesia, Us And Uk Perspective. Sociological Jurisprudence Journal. 3(2). 126-129. https://oi.org/10.22225/ scj.3.2.1832.126-129

\begin{abstract}
The absence of piercing the corporate veil doctrine in the Indonesian company law shows that the subsidiaries of such corporate groups are considered a separate legal personality, hence it is probably almost impossible to held the parent company liable for its subsidiaries' legal actions under any conditions. This research adopted a normative legal research with a comparative law study method. The goal of this research is describe the implementation of piercing the corporate veil doctrine in Indonesia, US and UK, then to make the points of contribution of this doctrine to be regulated properly in Indonesia. In fact, piercing the corporate veil doctrine is implemented in Indonesia, although there was not any normative legal basis of the doctrine itself, whereas in US and UK, the doctrine is implemented and further developed through precedents. Therefore, since there is an evident relationship between a parent company and its subsidiary, whereby in certain cases the parent company can and should be held liable for the acts of its subsidiary, there should be a more explicit regulation regarding both corporate groups and piercing the corporate veil doctrine.
\end{abstract}

Keywords: Company Law; Corporate; Limited Liability; Piercing The Corporate Veil

\section{INTRODUCTION}

In Indonesia, the concept of corporate group is not directly and specifically regulated by the constitution. Nonetheless, the idea of corporate group is not something new as it could be considered as a necessity in the ever-developing Indonesia's business community. With the concept of corporate group, many believe that a corporate could create a more efficient business. The existence of corporate group itself often generates polemics because it is frequently criticized as a management strategy that is in line with monopoly or unhealthy business practice. Not only that, the limit of liability of both the parent company and the subsidiary is also in a grey area because of the legal vacuum regarding corporate group practice. Therefore, when discussing the concept of corporate group, many often use Law of the Republic of Indonesia Number 40 of the Year 2007 concerning Limited Liability Companies (hereinafter referred to as "2007 Limited Liability Companies Law") and Law of the Republic of Indonesia Number 5 of the Year 1999 concerning the Ban on Monopolistic Practices and Unfair Business Competition (hereinafter referred to as "1999 Monopolistic Practices Law") as a reference or as a guideline. Nevertheless, as corporate law is developing rapidly, there are now a lot of large-scale business entities in Indonesia that do not operate in a single corporate form but in the form of corporate groups. In fact, these corporate groups, such as Semen Gresik Group, Astra Group, or Bakrie Group, only referred to the business reality of integrating several companies to create a corporate group as an economic unity. The absence of piercing the corporate veil doctrine in the Indonesian company law shows that the subsidiaries of such corporate groups are considered a separate legal personality, hence it is probably almost impossible to held the parent company liable for its subsidiaries' legal actions under any conditions.

On the other hand, the concept of corporate group is more common in the United States of America (hereinafter referred to as "US") and in the United Kingdom (hereinafter referred to as "UK"). Through 
the applications of the doctrine of piercing the corporate law by other countries such as US and UK, it could be deducted that it is important to implement the doctrine of piercing the corporate law under certain conditions and circumstances.

\section{METHOD}

This research adopted a normative legal research with a comparative law study method, whereby it will study the legal systems and statutes regarding piercing the corporate veil doctrine in Indonesia, US, and UK as well as the judicial cases, where the judges have used the piercing the corporate veil doctrine to pass judgments that are used as precedents to similar cases. Moreover, the judicial case study done in this research will also look into cases used as jurisprudence by the next judges as reference to pass a judgment. This research has the deductive approach as an approach of analysis, which usually starts generally and then specifically.

\section{RESULT AND DISCUSSION}

\section{The Implementation of Piercing the Corporate Veil Doctrine in Indonesia}

There are two cases in Indonesia that could be used to study the implementation of piercing the corporate veil doctrine, which are the case of PT Bank Perkembangan Asia (hereinafter referred to as "PT BPA") against PT Djaya Tunggal (hereinafter referred to as "PT Djaya") and the case of Su Meng Liang against PT Bank CIMB Niaga, Tbk. (hereinafter referred to as "Bank CIMB"). In the case of PT BPA against PT Djaya, the Supreme Court had upheld that the managers of PT Djaya, who were actually also the managers of PT BPA, should be subjected to the damages resulted from the loan given to PT Djaya by PT BPA with two expired title deeds as guarantee (Rissy, 2019; Sulistiowati \& Antoni, 2013). Furthermore, in the case of Su Meng Liang against Bank CIMB, the district court held that the personal assets of Su Meng Liang were to be confiscated to cover the damages of Bank CIMB resulted from the breach of credit agreement by PT Gunung Bintan Abadi (hereinafter referred to as "PT GBA"), which was represented by Su Meng Liang as the Main Director. The judgment was upheld by the Supreme Court, which stated that it was only fair to also confiscate the assets of Su Meng Liang as the Main Director of PT GBA. Hence, to see whether the doctrine of piercing the corporate veil could be implemented in these two cases in Indonesia, there is a need to look into whether the facts of the cases fulfilled one or all the grounds to pierce the corporate veil (Leander, 2017). The two cases above show that the doctrine of piercing the corporate veil is used by the judges in Indonesia in their legal considerations on the basis that there has been an action of the corporate done in bad faith and a fraud as well as a breach of contract due to negligent corporate governance by the managers, although in Indonesia itself, the piercing the corporate veil doctrine has not been regulated explicitly and only recognised to a certain extent.

\section{The Implementation of Piercing the Corporate Veil Doctrine in US}

There are two instances in the US, whereby piercing the corporate veil doctrine had been implemented. These two instances were in the case of Kinney Shoe Corp. v Polan in 1991 and Radaszewski by Radaszewski v Contrux Inc in 1989. In the case of Kinney Shoe Corp. v Polan in 1991, Kinney had a sublease agreement with Polan's company, Industrial Realty Company, which then Kinney filed a suit against for unpaid rent in 1987, yet the company had filed for insolvency at that time. Therefore, Kinney filed a suit against Polan individually, as the sole owner of Industrial Realty Company, to recover the amount of money owed by the company to Kinney (1991). On the other hand, in Radaszewski by Radaszewski v Contrux Inc in 1989, Radaszewski suffered a permanent injury in a car accident, whereby he was ran into by a truck driven by Dan Leslie Satterfield, who was an employee of Contrux. Contrux was a company entirely owned by Telecom and as Contrux was insolvent at the time of the lawsuit, Radaszewski had sued Telecom as the parent company of Contrux, claiming that the corporate veil of Telecom should be pierced to attribute to the tort of Satterfiels, an employee of Contrux (1989). In the case of Kinney Shoe Corp. v Polan (1991), the court used the Laya test to determine whether the corporate veil could be pierced for a breach of contract, whereby the test consists of the unity of interest and ownership between the corporate as a separate legal personality and the shareholder no longer exist and if the acts are treated as those of the corporation alone, an equitable result would 
occur. While in the implementation of piercing the corporate veil doctrine in Radaszewski v Contrux Inc. (1989), the court had established a test in order to pierce the corporate veil, which consists of there is a need for the party, who seeks to prove that two corporations are not two separate entities but one single unity, must be able to show that there is control of one corporation over the other, the control referred to must have been used to commit a wrong, a fraud, a dishonest and unjust act in breach of the other party's legal rights, or used to violate any statutory or legal duty and the control and acts committed mentioned above as well as the breach of duty must be proven to have proximately caused the injury complained.

\section{The Implementation of Piercing the Corporate Veil Doctrine in UK}

In Gilford v Horne (1993), whereby the defendant, who was a former employee at Gilford, held the position of a managing director. He was fired from the company, but his contract stated that he was not allowed to solicit or to attempt to solicit the customers of Gilford in the event that he left the company. Subsequently, Horne established a competing company that undercut the prices of Gilford's products. The English Court of Appeal held that Horne had set up his company to avoid his contractual obligations with Gilford. Therefore, the Court "pierce the corporate veil" and gave an injunction against Horne. The ruling of the Court of Appeal revealed that the Court could pierce the corporate veil in the event that a company is used as a mere device to avoid legal obligations. Similarly, in Jones v Lipman (1962), whereby Lipman had a contract with Jones, which stated that Lipman was to sell a house with a freehold title to Jones with the price of $£ 5,250.00$. However, pending the completion of the contract, Lipman decided to sell and transferred the house to a company for a price of $£ 3,000.00$, whereby the bank loaned a total of $£ 1,554.00$ to the company to purchase the land and the remaining amount was owed to Lipman. As it turned out, Lipman and a law clerk were, in actual fact, the sole directors and shareholders of the company that bought the land. Thus, the company had been established for the only purpose to purchase of the land. The English High Court pierced the corporate veil and held that the company was a sham or a façade that Lipman used to evade pre-existing legal obligation towards Jones (1962). These two cases of Gilford v Horne (1993) and Jones v Lipman (1962) created the one of the grounds to pierce the corporate veil which is the fraud doctrine, whereby judges use the façade test to see whether the company was created with fraudulent purposes and whether there is a misuse of the company.

In DHN Food Distributors Ltd v Tower Hamlets London Borough Council (1976), whereby DHN was a holding company in a group of the companies, the others being Bronze and DHN Food Transport, which were fully owned by DHN. In 1970, Tower Hamlets acquired the piece of land owned by Bronze and had paid the necessary compensation. However, the acquisition of the piece of land caused loses to DHN and thus DHN demanded compensation from Tower Hamlets. Lord Denning, in the Court of Appeal, explained that the compensation could only be granted to the owner of the land, which was Bronze, or other parties that rented the land whilst DHN was not recorded as the owner not a renter of the land. DHN was only recorded as the shareholder of Bronze, hence did not have the rights to demand compensation. From the perspective of piercing the corporate veil, Lord Denning argued that DHN as a holding company was a single entity, thus the three companies should be considered as a unity because of the same management they were under and the full control DHN had over the other two companies. This case of DHN Food Distributors Ltd v Tower Hamlets London Borough Council (1976) established another ground to pierce the corporate veil, which is the single economic unit doctrine. In this case, there were two criteria that needed to be fulfilled so that a parent company and its subsidiary could be considered as a single economic unit. The two criteria are whether the parent company holds the majority or all the shares of the its subsidiary and whether the parent company has decisive influence in its subsidiary's business operations.

The two grounds to pierce the corporate veil, which are the fraud doctrine and the single economic unit doctrine were used in the case of Adams v Cape Industries plc (1990), which established another ground to pierce the corporate veil, thus resulting in the three most common grounds used in the cases in English courts to pierce the corporate veil. In Adams v Cape Industries plc (1990), Cape Industries, which was a registered company in the UK and was a company that engaged in the asbestos mining business in South Africa, was sued by a worker from one of its subsidiaries in on the basis that he contracted a disease after inhaling asbestos dust. The company workers sued Cape Industries as parent company to be held liable and to pay compensation to the plaintiffs through a series of class actions. 
Through the lawsuit, there were three arguments that were raised: firstly, Cape Industries and its subsidiaries should be considered as one economic unit and should be treated by the law as such; secondly, the establishment of the subsidiaries of Cape Industries was simply a façade concealing the true sole purpose of limiting the liability of Cape Industries; and lastly, the application of agency theory whereby the subsidiaries of Cape Industries were merely agencies that made contracts for their principal, Cape Industries as the holding company, thus the parent company could be held liable should the subsidiaries suffered losses. The English court overthrown the three arguments and ruled Cape Industries as the holding company could not be held liable as it was a separate legal entity from its subsidiaries. Through the judgement in Adams v Cape Industries plc (1990), aside from the application of the two grounds to pierce the corporate veil, the court established another ground, which was the agency doctrine based on one of the three arguments raised by the plaintiff. According to the agency doctrine, the doctrine tests whether there is an establishment of agency relationship between the parent company and its subsidiary or not, which could clearly be seen when there is a clear consent given in written form to establish an agency relationship between the two companies. However, the agency doctrine could not be used when it was proven that the shares and operations of the subsidiary are not dominantly controlled by the parent company, which what happened in Adams v Cape Industries plc (1990).

\section{CONCLUSION}

The corporate veil could actually be pierced although the doctrine itself was not specifically regulated in the Indonesian company law. In fact, when the Supreme Court judges used the doctrine in their legal considerations. In US, there are two tests tried by the judges to determine whether piercing the corporate veil doctrine could be used. The implementation of the doctrine could be seen to have been based on grounds that there might be fraudulent intent by establishing corporates as alter egos and breach of rights that caused injuries to the other party. In UK, there are three grounds to pierce the corporate veil established and used in the cases in UK. The first doctrine is the fraud doctrine, the second one is single economic unity doctrine, and the third one is the agency doctrine. These grounds from US and UK, should be a contributed materials for Indonesia to awake itself in reforming the Company Law in order to boost the business.

\section{REFERENCE}

Adams v Cape Industries plc [1990] Ch 433.

DHN Food Distributors Ltd v Tower Hamlets London Borough Council [1976] WLR 852.

Gilford Motor Co Ltd v Horne [1993] Ch 935.

Jones v Lipman [1962] 1 W.L.R. 832.

Kinney Shoe Corp. v Polan, 939 F.2d 209 (4th Cir. 1991).

Leander, J. (2017). Penerapan Doktrin Piercing the Corporate Veil dalam Praktek Perseroan Terbatas dalam Putusan Mahkamah Agung Republik Indonesia (MARI) (Studi Putusan Perkara Nomor 1916/K/PDT/1991 dan Nomor 1311/K/PDT/2012) [Implementation of Piercing the Corporate Veil Do. Premise Law Jurnal, 22, 1-16. Retrieved from https://jurnal.usu.ac.id/index.php/premise/article/view/21676

Radaszewski by Radaszewski v Telecom Corp., 981 F.2d 305 (8th Cir. 1992).

Rissy, Y. Y. W. (2019). Doktrin Piercing the Corporate Veil: Ketentuan dan Penerapannya di Inggris, Australia dan Indonesia. Refleksi Hukum: Jurnal Ilmu Hukum, 4(1), 1-20. Retrieved from https://doi.org/10.24246/ jrh.2019.v4.i1.p1-20

Sulistiowati, \& Antoni, V. (2013). Konsistensi Penerapan Doktrin Piercing the Corporate Veil pada Perusahaan Terbatas di Indonesia. Yustisia Jurnal Hukum, 2(3), 23-33. Retrieved from https://doi.org/10.20961/ yustisia.v2i3.10152 